\title{
OPINIA \\ O PROJEKCIE ZMIANY USTAWY O MNIEJSZOŚCIACH NARODOWYCH I ETNICZNYCH ORAZ $O$ JĘZYKU REGIONALNYM, A TAKŻE NIEKTÓRYCH INNYCH USTAW ${ }^{1}$
}

Keywords: Silesia, subdialect, dialect, regional language, legal status

Słowa klucze: Śląsk, gwara, dialekt, język regionalny, status prawny

Spis treści: Wstęp; I Wykaz błędów i nieścisłości o charakterze językoznawczym i historycznym; II Tworzenie przez zwolenników języka śląskiego faktów dokonanych; III Strategia działania według zasad tzw. rewitalizacji języków; IV Kaszubszczyzna (język regionalny) jako wzór dla wnioskodawców; V Obraz sytuacji na Śląsku - „wojna śląsko-śląska/polska”; VI Uwagi o dotychczasowych opiniach do ustawy; VII Uwagi o sytuacji polityczno-społeczno-edukacyjnej w województwie śląskim; VIII Konieczność podniesienia prestiżu gwar i regionalizmów w Polsce; IX Zakończenie

\section{Wstęp}

Podpisana przez Polskę Europejska karta języków regionalnych i mniejszościowych mówi wyraźnie o tym, że za język regionalny można uznać język niebędący dialektem $^{2}$. Tymczasem proponowane zmiany w Ustawie... odnoszą się do śląszczyzny,

1 Opinia ta powstała na zamówienie Sejmu RP jesienią 2012 r. Redakcja „LingVariów” serdecznie dziękuje Pani dr Bożenie Cząstce-Szymon za zgodę na jej opublikowanie.

2 W Preambule jest mowa o tym, że celem Europejskiej karty... jest ochrona tych historycznych języków regionalnych lub mniejszościowych, którym grozi wyginięcie. 
która jest regionalną/terytorialną odmianą języka polskiego, czyli dialektem. Tak jest kwalifikowana przez wszystkie liczące się naukowo opracowania (encyklopedie, słowniki). Taką też kwalifikację gwary śląskiej utrzymuje Biblioteka Kongresu Stanów Zjednoczonych.

\section{Wykaz błędów i nieścisłości o charakterze językoznawczym i historycznym}

Ponieważ jednak Uzasadnienie, liczące 8 stron, zawiera liczne błędy, nadinterpretacje i dane niezgodne z rzeczywistością, chciałabym na początku je wymienić i opisać:

1. Nie jest prawdą, jakoby w klasyfikacji ISO: 639-3 $3^{3}$ znajdował się język śląski, Silesian określany jest tam jako a dialect of Polish [pol], podobnie jak Silesian in Czech Republic a dialect of Polish [pol].

2. Nie jest prawdą, że Biblioteka Kongresu Stanów Zjednoczonych traktuje śląszczyznę jako język; nadal jest ona zaliczana do polskich gwar.

3. Nie jest prawdą, że „slawiści amerykańscy od co najmniej kilkudziesięciu lat klasyfikują za amerykańską Encyklopedią Słowiańską śląski język jako odrębny twór językowy” oraz nieprawdziwa jest informacja, że „od wielu lat także w międzynarodowych środowiskach naukowych slawistów podejmowane są próby klasyfikacji języka śląskiego jako odrębnego języka słowiańskiego".

4. Wiele rażących błędów i nieścisłości można zauważyć w klasyfikacji tzw. etnolektu śląskiego:

a. Na stronicach 9-10 podaje się podział na trzy części - cieszyński, środkowy i opolski ${ }^{5}$, a na s. 12 okazuje się, że ,język śląski występuje w postaci czterech (! B.C.-S.) podstawowych dialektów z licznymi odmianami...”.

b. Wcześniej na stronach 9-10 dokonuje się podziału śląszczyzny na jedenaście dialektów z niestosowanym w naukowych opracowaniach gwaroznawczych wyodrębnianiem np. „dialektu pogranicza śląsko-małopolskiego: Katowice, Tychy, powiat pszczyński” oraz „dialektów pogranicza gliwicko-opolskiego: powiatu tarnogórskiego i lublinieckiego". Ważną cechą gwar pogranicza śląsko-małopolskiego jest tzw. mazurzenie (czyli wymowa występująca w licznych polskich gwarach, typu kasa zamiast kasza, coło zamiast czoło), gwary te rozciągają się wąskim pasem od Pszczyny po okolice Tarnowskich Gór i Lublinieckie.

c. Gwar centralnych nigdy dialektolodzy nie nazywali - ,pyskowickimi, rybnickimi, mikołowskimi” (jak na s. 9 Uzasadnienia), ale gwarami toszecko-gliwickimi.

3 Por. http://www.sli.org/iso639-3/ oraz http://www.sil.org/iso639-3/documentation.asp?id=szl

4 Autorzy Uzasadnienia opierają się tu na popularnym opracowaniu z 1949 r. pod red. J. Roucka Slavonic Encyclopaedia, gdzie krótkie hasło Silesian Idiom \& Language (por. s. 1149-1151) opracował czesko-żydowski tłumacz poezji, Ewald Osers. Hasło to rozpoczyna zdanie: „Silesia has for a long time been the cinderella of Slavonic studies".

5 Nie wiadomo dlaczego pisane w Uzasadnieniu wielką literą... 
d. Błędem jest pominięcie gwar południowocieszyńskich (dawnego Księstwa Cieszyńskiego), historycznie sięgających po rzeki - Łucynę i Stonawkę. Później dopiero teren, na którym gwary te występują, został nieco zawężony w południowo-zachodniej części, obecnie zaś należy on do Czech i nazywany jest od $1919 \mathrm{r}$. Zaolziem.

e. Niedopuszczalne jest następujące określenie: „dialekt jabłonkowski': okolice Wisły" (s. 10).

f. Kuriozalnie nazwano „dialekty północne (!): powiat raciborski na zachód od Odry".

g. Dodajmy, że zniknęły z przedstawionego podziału gwary opolskie (Krysioków), oleskie, kozielskie..., a przecież stanowią one trzon gwar śląskich Opolszczyzny.

h. Podkreślmy ponadto, że co najmniej dyskusyjne jest włączenie dialektu laskiego ${ }^{7}$ do śląszczyzny.

5. W żadnej z poważnych publikacji naukowych nie znajdzie się określenia, że śląszczyzna to ,jeden z języków zachodniosłowiańskich, wywodzących się wprost z języka prasłowiańskiego"; taka definicja świadczy o ignorancji autorów, o ahistorycznym podejściu do podziału języków słowiańskich (na południowe, wschodnie i zachodnie; dopiero te ostatnie rozdzieliły się na grupy czesko-słowacką, łużycką i lechicką, a ta z kolei rozwarstwiła się na grupy: połabską, pomorską, z której wywodzi się kaszubszczyzna, i polską).

6. Manipulacyjno-ahistoryczny charakter ma informacja (s. 9) dotycząca „prób standaryzacji literackiego języka śląskiego, podejmowanych [...] przez popularnego na Górnym Śląsku poetę ks. Antoniego Stabika"8. Kapłan ten był znanym kaznodzieją, działał też w obronie społeczności polskiej na Śląsku, pisał wiersze, był autorem sztuki napisanej po polsku; ale nie mamy żadnych dowodów uzasadniających tezę o standaryzacji przez niego śląszczyzny.

7. Dezinformujący charakter ma stwierdzenie, jakoby „dialektolog rodem z Baborowa (!) na Opolszczyźnie, Feliks Steuer, opracował odrębną pisownię śląskiej mowy [...]" (por. s. 10). Prawdą natomiast jest to, że Feliks Steuer (urodzony w 1889 r.

6 Sama nazwa jabłonkowskie wskazuje, że gwarami tymi posługują się mieszkańcy okolic Jabłonkowa na Zaolziu. Cechą charakterystyczną tamtejszej wymowy jest tzw. siakanie (jabłonkowanie): maszina jedżie do Czieszina. Występuje ona też w trzech wioskach po polskiej stronie: Jaworzynce, Koniakowie i Istebnej, ale nie w Wiśle! (wymowę taką usłyszymy też w północnej Polsce, w gwarach malborsko-lubawskich i ostródzkich).

7 O genezę dialektu laskiego spierali się kilkadziesiąt lat temu dialektolodzy polscy i czescy. Współcześnie gwar laskich nie zalicza się do polskich dialektów, por. Encyklopedia języka polskiego, pod red. S. Urbańczyka, Wrocław - Warszawa - Kraków 1991, s. 191.

8 Por. biogram ks. A. Stabika (1807-1887) w Słowniku biograficznym katolickiego duchowieństwa śląskiego XIX i XX wieku, pod red. M. Patera, Katowice 1996. 
w Sulkowie, ostatniej polskiej wsi na pograniczu śląsko-morawskim) na zlecenie prof. Kazimierza Nitscha przygotował znakomitą monografię swej rodzimej gwary i zastosował w niej pisownię półfonetyczną; dodajmy, że autor korzystał z subwencji PAU. Drugą monografię gwary baborowskiej napisał w roku $1937^{10}$, obydwie wydał w Krakowie; o jego propolskiej postawie świadczy to, że po plebiscycie przeniósł się z opolskiego Sulkowa do Katowic, gdzie pracował jako nauczyciel (był dyrektorem polskiego gimnazjum).

8. Nieprawdziwe i krzywdzące jest przypisywanie wybitnemu slawiście niemieckiemu, rodowitemu Ślązakowi, profesorowi Reinholdowi Oleschowi traktowania śląszczyzny jako odrębnego języka (por. s. 9 Uzasadnienia); językoznawca ten, doktor honoris causa, m.in. UAM w Poznaniu i uniwersytetu w Opolu, w każdej publikacji poświęconej śląszczyźnie używał terminu Mundart, Dialekt; w pracach drukowanych w czasach hitlerowskich (1937) nie mógł używać przymiotnika polski, zastąpił go „slawischen Dialekte”. Nie uchroniło go to jednak przed uznaniem przez Reichschrifttumskammer jego monografii gwar śląskich za szkodliwą i niepożądaną ${ }^{11} \mathrm{i}$ przed zwolnieniem z pracy na uniwersytecie w Greifswaldzie. Dodajmy, że studenci spalili w Berlinie wiele egzemplarzy wspomnianej publikacji, a naukowiec powrócił do pracy dopiero po interwencji profesora M. Vasmera.

9. Nieprawdą jest, że po 1945 r. „istniał żywy język pomorskich Słowińców” (w okolicach Kluk żyło wówczas kilka zaledwie rodzin znających poszczególne słowa słowińskie) ${ }^{12}$.

10. Nieprawdziwa jest teza, że łemkowszczyzna jest gwarą języka rosyjskiego (!), a nie ruskiego/ukraińskiego. Taki zapis świadczy o niewiedzy autorów Uzasadnienia (por. s. 8).

11. Przypisanie pojawienia się Słownika gwar ślaskich pod. red. B. Wyderki fali rozwoju zainteresowania po roku 1989 śląską tradycją, kulturą i mową uważam za nadużycie, ponieważ materiały do tego leksykonu zbierali profesorowie S. Bąk i S. Rospond przez wiele lat, i to oni wydali Słownik gwarowy Ślaska. Zeszyt próbny, który ukazał się w Opolu w 1982 r. (publikacja pt. O zbieraniu materiałów gwarowych na Śląsku autorstwa S. Bąka została wydrukowana jeszcze w 1937 r.).

9 Por. Dialekt sulkowski, Kraków, PAU 1934.

10 Por. Dialekt baborowski, Kraków, PAU 1937.

11 Por. artykuł J. Ruska pt. Zastugi Reinholda Olescha dla slawistyki (Slawistyka niemiecka a kraje słowiańskie), red. J. Rusek, Warszawa 1998.

12 Por. Z. Sobierajski, Podsumowanie badań nad nagraniami reliktów gwary kaszubskich Słowińców, [w:] J. Zieniukowa (red), Obraz językowy słowiańskiego Pomorza i Łużyc. Pogranicza i kontakty językowe, Warszawa 1997, s. 59-68. 
W Uzasadnieniu pojawiły się również pewne nieścisłości historyczne:

- niewiarygodne jest podanie dla roku 1849 zmniejszenia ludności śląskojęzycznej do $58,6 \%$, ponieważ mamy dane ${ }^{13} \mathrm{w}$ postaci list niemieckich, które bardzo precyzyjnie podawały ilości polskojęzycznych i niemieckich mieszkańców Śląska w poszczególnych powiatach Górnego Śląska od początku XIX w. aż do roku $1910^{14}$. Są też niemieckie mapy (np. J. Partscha), wytyczające granice językowe polsko-niemieckie. Dodajmy, że w połowie XIX w. wskutek systematycznego kurczenia się terenów zamieszkałych przez ludność polskojęzyczną Ślązacy zasiedlali już tylko tereny na wschód od Wrocławia ${ }^{15}$.

\section{Tworzenie przez zwolenników języka śląskiego faktów dokonanych}

Obserwując działania zwolenników języka śląskiego, można dostrzec swoistą strategię, jaką stosują oni od pięciu lat. Polega ona na tworzeniu faktów dokonanych.

Działania te rozpoczęto w marcu 2007 r., kiedy to działacze Związku Ludności Narodowości Śląskiej ${ }^{16}$ wystąpili do Biblioteki Kongresu Stanów Zjednoczonych z wnioskiem o wpisanie języka śląskiego do rejestru języków świata. We wniosku podano argument, że "nowy" rejestrowany język (śląsko godka, śląsko spracha) jest najbardziej podobny do języka morawskiego ${ }^{17}$ (na drugim miejscu wymieniono język czeski, a dopiero na trzecim - język polski), ponadto - niemiecki (w przypadku kreola śląskiego ${ }^{18}$ ). Częścią tego wniosku była lista 67 pozycji rzekomo zapisanych językiem śląskim. Wnioskodawcy zamieścili wśród nich słowniki gwarowe, m.in. naukowy słownik R. Olescha, Der Wortschatz der polnischen Mundart von Sankt Annaberg [Słownik polskiej gwary Góry Świętej Anny], Mały słownik gwary Górnego Ślaska mojego współautorstwa, teksty literackie i paraliterackie stylizowane na gwarę, teksty folklorystyczne i - co wydaje się kuriozalne - utwory muzyczne: Tryptyk ślaski: na sopran i orkiestrę symfoniczną Witolda Lutosławskiego (1953). Nie uwzględniono natomiast podstawowego opracowania Dialekty polskie Śląska K. Nitscha oraz publikacji dotyczących gwary i kultury na Śląsku o tytułach zawierających określenie: polskie.

Równocześnie zaczęła się wzmożona działalność popularyzatorska (np. „Dyktando po śląsku") i wydawnicza (autorów nieprofesjonalnych); opublikowano Wielki słownik ślasko-niemiecko-angielski A. Czajkowskiego, L. Schroeder i S. Schroeder, Słownik

13 Por. A. Galos, Polskość Śląska w XIX wieku, [w:] Szkice z dziejów Ślaska, t. II, Warszawa 1956, s. 39; por. też Encyklopedia powstań ślaskich, Opole 1982, s. 399.

14 Wykazy te obejmowały miasta i powiaty rejencji opolskiej (28 pozycji).

15 O tym, że w pocz. XIX w. Ślązacy mieszkali jeszcze w okolicach Wrocławia, świadczy słowniczek Baltazara Działasa i pamiętniki podróżujących przez Śląsk Polaków.

16 Związek ten do tej pory nie został zarejestrowany przez sąd.

$17 \mathrm{~W}$ opracowania językoznawczych nie wyodrębnia się takiego języka.

18 Są to echa poglądów radcy rejencji opolskiej Johanna Bendy (z roku 1820), podtrzymywanych przez Ottona Fischera i Heinricha Wuttkego (w 1868 r. i upowszechniane później), iż lud śląski mówi mieszaniną czesko-morawsko-polsko-niemiecką (Kowalska 2002). 
etymologiczny gwary śląskiej B. Paździora, Słownik gôrnoślônskij godki B. Kallusa; zaczęto wydawać czasopismo "Ślonsko Nacyjo" ${ }^{19}$ oraz inne śląskie gazety, stosujące różne sposoby zapisu śląszczyzny, np. Jaskółka, organ RAŚ, „Ślůnski Cajtůng”, czasopismo górnośląskie i inne. Problem śląszczyzny nagłaśniano w mediach tak, jakby gwara śląska była już uznana za osobny język ${ }^{20}$.

We wrześniu 2007 r. 23 posłów reprezentujących różne opcje polityczne wystąpiło w Sejmie z wnioskiem o zakwalifikowanie śląszczyzny do języków regionalnych. W grudniu 2007 r. wniesiono po raz pierwszy do Sejmu RP projekt zmiany ustawy o mniejszościach z uzasadnieniem. W uzasadnieniu tym pojawiły się liczne błędy rzeczowe $^{21}$, nieprawdziwe stwierdzenia i powoływanie się na niezgodne z prawdą opinie znanych slawistów ${ }^{22}$.

W 2008 r. powstały dwa towarzystwa: Pro Loquela Silesiana oraz Towarzistwo/Ferajn Piastowanio i Promowanio Ślonskij Mowy „Danga”, a kilka lat wcześniej pojawiła się Ślonsko Nacyjno Łoficyno. Założono też w 2008 r. Ślonską Wikipedię, która jednak nie jest kontynuowana. Działała również regionalna telewizja Silesia TVS, a programy radiowe nadawane gwarą śląską można usłyszeć i w samorządowym Radiu Piekary, i w lokalnych stacjach, i w Radiu Katowice.

W czerwcu 2008 r. w Sali Sejmu Śląskiego odbyła się konferencja, zorganizowana z inicjatywy Ruchu Autonomii Śląska pod znamiennym tytułem „Śląska godka czy jednak już język", zdominowana przez prelegentów opowiadających się za językiem śląskim (m.in.: T. Kamusella, B. Kallus, A. Czesak i inni, związani z Ruchem Autonomii Śląska).

Zaczęto wydawać materiały dydaktyczne, np. ślabikorze do nauki języka śląskiego w I i III klasie (2010 r.), zorganizowano lekcje nauczania języka śląskiego w Muzeum Śląskim w Katowicach. Rozwinęła się produkcja gadżetów, koszulek „organizacyjnych” dla członków i sympatyków śląskiego separatyzmu z napisami „Nie Polak, nie Niemiec Ślązak”, „Ich bin Schlesier”, nadruki na samochody: „Oberschlesien” i inne.

Początkowo działacze RAŚ wysuwali powołanie języka śląskiego jako główny warunek istnienia narodowości śląskiej: „Naród musi mieć swój język” - pisał Andrzej Roczniok, ale później zmodyfikowali to stanowisko: język regionalny ma być traktowany jako pomocniczy. Równocześnie jednak na zjeździe RAŚ w Katowicach

19 Początkowo ukazywał się jako miesięcznik.

20 Ogólnopolska prasa, radio i telewizja w entuzjastycznym tonie informowały o istnieniu języka śląskiego. Jednakże dziennikarze nie sprawdzili informacji, czy Biblioteka Kongresu USA wprowadziła korektę do obecnej klasyfikacji języków słowiańskich.

21 Wymieńmy niektóre z nich: języki słowacki i czeski różni jedynie kilka cech fonetycznych (s. 7 Uzasadnienia), mowa śląska ulega szybkiej deformacji pod wpływem języka polskiego (s. 12), wielu naukowców w kraju i zagranicą (sic!) traktuje język śląski za odrębny język zachodniosłowiański...

22 Np. Reinholda Olescha, a przecież ten uczony stwierdzał, iż udowodnienie polskości gwary śląskiej nie sprawia żadnych trudności i że nigdy nie była ona w badaniach dialektologicznych stawiana pod znakiem zapytania (Grybosiowa 1998, por. też Borek 2007). 
(5-6 marca 2011 r.) uchwalono strategię działań - dążenie do decentralizacji państwa $^{23}$, co jest związane ze zmianą Konstytucji RP (zmiana z państwa unitarnego na federacyjne!).

Poszczególne etapy działań w sprawie uznania języka śląskiego były żywo komentowane w mediach, a artykuły prasowe były utrzymane w swoistej stylistyce - używano sformułowań z wykorzystaniem metaforyki militarnej, frazeologii batalistycznej i katastroficznej, a w nagłówkach artykułów oceniano z pozycji sukcesów lub klęski efekty starań o zakwalifikowanie gwary śląskiej do języków regionalnych ${ }^{24}$.

\section{Strategia działania według zasad tzw. rewitalizacji języków}

Można zaobserwować, że śląscy zwolennicy języka regionalnego postępują według „instrukcji rewitalizacyjnej”. Stwarza się lobby (lokalne gazety, próby nacisku na tzw. celebrytów). Powstają liczne publikacje (przez kogo dotowane?) o niskim poziomie merytorycznym i napastliwym tonie. Wydawnictwa te ukazują się bez recenzji. Stosuje się presję na zwolenników zachowania gwary (będących przeciwnikami ustalenia języka śląskiego) w postaci artykułów w prasie oraz drastycznych w tonie zapisów w Internecie.

Wszystko to pokazuje działania, które socjolingwiści stosują w odniesieniu do wymierających języków mniejszości etnicznych. Jest to tzw. „odwracanie procesu obumierania języka". Chodzi o wyznaczanie/stosowanie dziesięciu etapów rewitalizacji mowy ${ }^{25}$. W przypadku śląszczyzny problem polega jednak nie na odnowie języka ale - na dowartościowaniu gwary, która przecież nie zanika ${ }^{26}$. Tam gdzie rodziny i otoczenie jej nie pielęgnują, nie da się poprzez ustawę zmienić tego faktu, że podobno młodsze pokolenie nie posługuje się już gwarą ${ }^{27}$.

23 Wcześniej pisał o tym T. Kamusella w artykułach polsko- i anglojęzycznych.

24 Np.: „Wielka haja o śląską godkę!”; „Następny pocisk z arsenału spisku tropicieli autonomistów”; "Strachy przed językiem śląskim, czyli pięć demonów”; „Ratujmy śląszczyznę”; „Dzwony biją na trwogę”; „Zaczyna się druga runda walki o język, kulturę, etniczność”; „Śląski dostał bolesny cios”; „Nie wygraliśmy pod Legnicą, nie mamy języka śląskiego”; „Duchowość [celtycka] Ślązaków jest jak bastion”; „Ci, którzy pokazują, gdzie jest miejsce gwary, są strażnikami narodowych szańców”; „Wciąż przelewamy krew za śląską godkę”, „Czwarta wojna śląska”.

25 A.F. Majewicz, T. Wicherkiewicz, Polityka językowa na Kaszubach na tle prawodawstwa wobec mniejszości w jednoczącej się Europie (diagnoza i postulaty), [w:] E. Breza, Kaszubszczyzna, Kaszebizna, Opole 2001, s. 81-98.

26 Pokazują to badania, przeprowadzone w Uniwersytecie Śląskim, które oceniają znajomość gwary śląskiej wśród uczniów na $40 \%$.

27 Tak twierdzą zwolennicy „ratowania śląszczyzny” i planują wykorzystać doświadczenie działaczy europejskich odnawiających m.in. języki celtyckie, szukają też doradców w Bawarii. 


\section{Kaszubszczyzna (język regionalny) jako wzór dla wnioskodawców}

Skoro Autorzy Uzasadnienia powołują się często na Kaszubów i ich uwieńczone sukcesem starania o uznanie regionalnego języka kaszubskiego (ten przypadek przywołują też opiniodawcy, np. J. Tambor, T. Wicherkiewicz, M. Szczepański), warto byłoby jednak napisać, jakie są negatywne skutki tego faktu (bo zwykle podaje się tylko plusy). Okazuje się, że młodzież nie jest specjalnie zainteresowana zdawaniem matury po kaszubsku (dwa lata temu tylko sześciu uczniów zdawało taką maturę).

Należy zatem wyraźnie uzmysłowić sobie, do czego dochodzi na Kaszubach. Żywa kaszubszczyzna w postaci kilkudziesięciu gwar spotykana jest w naturalnym środowisku wiejskim, w szkołach jednak uczy się języka kaszubskiego, którego w domu się nie używa. W kościele (w zależności od tego, którą z gwar kaszubskich wierni się posługują) rozumie się czasem tylko ok. $20 \%$ tekstów liturgicznych. Pojawiły się już słowniki polsko-kaszubskie (A. Labudy ${ }^{28}$, II wydanie), gdzie autor wymyślił ok. 580 nowych wyrazów (przy czym oznaczył je jako neologizmy), ale już jego następca, J. Trepczyk ${ }^{29}$, notuje 2000 wyrazów kaszubskich, dla których nie podaje kwalifikatorów (!), tzn. nie wiemy, które wyrazy są rzeczywiście używane w kaszubszczyźnie, a które zostały stworzone przez autora słownika. Jak pisze najwybitniejsza znawczyni kaszubszczyzny, prof. H. Popowska-Taborska ${ }^{30}$, jest to celowa i przemyślana działalność zmierzająca do sztucznego wzbogacenia kaszubskiego słownictwa. Cechą charakterystyczną neologizmów jest to, by się maksymalnie różniły od polskiego wzorca słowotwórczego...

\section{Obraz sytuacji na Śląsku - „wojna śląsko-śląska/polska”}

Pomniejsza się osiągnięcia polskie, a nadmiernie eksponuje niemiecką historię Śląska (por. wytyczne do projektu wystawy w Muzeum Śląskim w Katowicach ${ }^{31}$ ): wymienianie np. noblistów, urodzonych lub mieszkających pewien czas na Śląsku (większość z nich to byli Żydzi lub Niemcy), którzy reprezentowali naukę niemiecką, a pomijanie informacji o śląskich uczonych światowej sławy - Janie Wyplerze (sinologu z Kochłowic) i Rudolfie Ranoszku (z Moszczenicy k. Wodzisławia, znawcy kultury babilońskiej, asyryjskiej i hetyckiej). Na liście znanych Ślązaków nie znalazł się też prymas August Hlond, uważany obok W. Korfantego za najwybitniejszego reprezentanta tej ziemi, nie wymieniono również Henryka Sławika, który podczas II wojny światowej uratował na Węgrzech kilkadziesiąt tys. Polaków, w tym ok. 5000 polskich Żydów... Jeśli

28 A. Labuda, Słownik polsko-kaszubski. Słowôrz kaszëbsko-polsczi, Gdańsk 1982.

29 J. Trepczyk, Słownik polsko-kaszubski, Gdańsk 1994.

30 H. Popowska-Taborska, Leksyka kaszubska na tle słowiańskim, Warszawa 1996.

31 Przez kilka tygodni w śląskiej prasie trwała dyskusja nad wytycznymi do wystawy, odkrytymi w Internecie przez jedną z dziennikarek; podkreślmy, że i dyrektor muzeum, i przewodnicząca rady muzealnej znani są z sympatii dla autonomistów. 
dodamy do tego stałe dyskusje nt. walk bratobójczych podczas powstań śląskich oraz w czasie II wojny światowej ${ }^{32}$, wybiórczość faktów historycznych w różnych okresach, to wnioski o manipulowaniu wydarzeniami z przeszłości są wyraźne.

Brak rozpatrywania na szerszym tle tzw. krzywdy śląskiej (wywózek Ślązaków po 1945 r. do ZSRR oraz osadzania ich w obozach pracy, m.in. na Zgodzie, w Oświęcimiu, jednak w obozach tych przetrzymywano też polskich harcerzy, akowców i żołnierzy wyklętych) pokazuje stronniczość i manipulacyjne działania miejscowych dziennikarzy, licznych historyków i decydentów, z których wielu ma powiązania $\mathrm{z}$ autonomistami.

W roku 2009 znana badaczka śląskiego folkloru, prof. D. Simonides, ostrzegając przed rejestracją języka śląskiego, zwracała uwagę na prawdopodobieństwo waśni i roszczeń. Minęło kilka lat i rzeczywistość śląska pokazuje, ile przenikliwości było w tych ostrzeżeniach. Nie ma częstszego tematu w miejscowej prasie jak powstanie języka śląskiego. Sytuacja jest czarno-biała: ci źli - to zwolennicy zachowania śląszczyzny w kontaktach domowo-rodzinno-sąsiedzkich oraz lokalnych (tam, gdzie gwara jest naturalnym sposobem komunikowania się), ci dobrzy - to zwolennicy języka śląskiego na początku regionalnego, a potem chyba już oficjalnego, zgodnie z głoszonym przez członków RAŚ hasłem, że Ślązacy to naród, a śląszczyzna to język.

Stale są krytykowani za swe propolskie poglądy rodowici Ślązacy: arcybiskup katowicki ${ }^{33}$, były wiceminister, wybitny sędzia Sądu Najwyższego, prezes Towarzystwa Przyjaciół Śląska w Warszawie, wicemarszałak Senatu, twórczyni konkursu „Po naszymu, czyli po śląsku”, popularyzująca od przeszło 20 lat gwary śląskie, znakomity znawca dziejów Śląska, pedagog, drugi rektor Uniwersytetu w Opolu ${ }^{34}$, wybitna znawczyni i popularyzatorka folkloru śląskiego, senator kilku kadencji, autor licznych publikacji popularnonaukowych i popularnych o Śląsku.

Nie mówiąc już o profesorach, językoznawcach, prowadzących badania dialektologiczne oraz upowszechniających rzetelną wiedzę o Śląsku dziennikarzach (o śląskim i nieśląskim rodowodzie), których opatruje się niewybrednymi epitetami. Doszło do śląsko-śląskiej wojny („Ślązak przeciw Ślązakowi”, por. tytuł wywiadu z drem J. Musiołem). Ze względu na to, że 80\% prasy jest w rękach kapitału niemieckiego, $\mathrm{w}$ miejscowych gazetach przewagę stanowią artykuły popierające wprowadzenie języka śląskiego.

32 Ślązacy podczas II wojny światowej walczyli na obydwu frontach (dodajmy, że większość żołnierzy ze Śląska, siłą wcielonych do Wehrmachtu, wróciła na Śląsk, wcześniej wielu uciekało do polskiego wojska na Zachodzie, byli też Ślązacy w I i II Armii WP.

33 Por. „Ślunski Cajtůng” nr 9, wrzesień 2012 „Arcybiskup [...] kontynuuje polonizację Ślązaków. [...] Jeśli tak dalej pójdzie, to setki tysięcy Ślązaków-katolików będą musiały zastanowić się nad formą protestu przeciw polonizacji w wykonaniu katowickiego arcybiskupa. Może skuteczne okażą się masowe listy [...] do samego Ojca Świętego...”.

34 Por. artykuł L. Frelicha w: „Opole.gazeta.pl” z 8.04.2012 r., pt. Profesor Marek bajdurzy o Śląsku. 


\section{Uwagi o dotychczasowych opiniach do ustawy}

Wnioskodawcy zmiany Ustawy o mniejszościach... dołączyli sześć opinii w roku 2008, w tym ekspertyzę z Asturii (?), trzy zamówił Sejm w 2011 r., dodajmy, że dwukrotnie ekspertyzę pisała ta sama autorka. Należy podkreślić, że nie było do tej pory opinii historyków i prawników. Teksty opinii eksperckich mają niejednokrotnie charakter kontrowersyjny. Przyjrzyjmy się wybranym fragmentom: np. profesor socjologii Marek Szczepański próbował projektować działania polityczne związane z językiem śląskim na... Zaolziu, pisząc: „Język śląski występuje także na terenie Republiki Czeskiej. Parlament RP i obie jego izby stanowią prawo na terenie kraju, ale wydaje się wskazane podjęcie bilateralnych rozmów na temat obecności języka śląskiego u południowych sąsiadów”. Informacja M. Szczepańskiego jest sprzeczna z rzeczywistością i dowodzi braku orientacji socjologa nie tylko w kwestiach narodowościowych na Zaolziu, ale i w sprawach szkolnictwa polskiego na tym terenie. Przez ponad 1oo lat istniały tam do niedawna dwa polskie licea (teraz jest jedno oraz Akademia Handlowa i inne szkoły średnie z lekcjami języka polskiego), funkcjonuje 25 polskich szkół podstawowych i 33 przedszkola oraz klasy o polskim profilu narodowym w szkołach zawodowych ${ }^{35}$.

Z kolei profesor B. Wyderka w swej opinii, która bardzo dobrze orientuje w badaniach dialektologicznych na Śląsku od poł. XIX w., podaje kilka faz wyłaniania się nowego, śląskiego języka, pokrewnego polszczyźnie. Zmiana stanowiska językoznawcy w stosunku do jego wcześniejszych poglądów (Wyderka 2011) nie ma uzasadnienia w badaniach naukowych. Autor nie wziął pod uwagę danych ilościowych dotyczących tej grupy Ślązaków, którzy dopominają się, by uznać gwarę śląską za język. Wówczas gdy formułował on swoją opinię, prasa informowała, że 54 tys. osób posługuje się tą gwarą $^{36}$. Jest to i tak mało wobec populacji rodowitych mieszkańców Śląska. Zaskakuje również - wyrażany przez językoznawcę pogląd - o innym zakresie używania gwary śląskiej na terenie Śląska przemysłowego, innym zaś na Opolszczyźnie i w Cieszyńskiem. Obserwacje zachowań językowych rdzennych skoczowian i cieszynian w różnych sytuacjach komunikacyjnych dowodzą, że - podobnie jak na Śląsku przemysłowym - używają oni rodzimej gwary w lokalnych i półoficjalnych kontaktach (np. w sklepie, w szpitalu, w szkole - na przerwie).

W odniesieniu do opinii J. Tambor - nie można zgodzić się z konstrukcją definicyjną, że jeden byt (śląszczyzna) raz jest gwarą, a raz językiem regionalnym, bo to już przypomina kwalifikacje ślimaka jako ryby i marchewki jako owocu w specyficznych unijnych ustaleniach i nie uwzględnia systematyki naturalnej.

$35 \mathrm{Na}$ terenie tym kształci się od lat potrójną kompetencję językową (polską, czeską i gwarową, śląską) uczniów, pisały o tym m.in. Janina Labocha (1996), Bożena Cząstka-Szymon, Zofia Matyskowa (1997), Iwona Nowakowska-Kempna (1997) oraz Irena Bogocz (1998).

36 Nie mamy jednak dowodów, że posługujący się gwarą w domu chcieliby uznania śląszczyzny za język regionalny. 
We wszystkich opiniach ekspertów do wniosku o uznanie śląszczyzny za język autorzy zakładają, że gwarze śląskiej (etnolektowi) zostanie przyznany status języka regionalnego i prognozują dalsze przedsięwzięcia (działania), nie dopatrując się wszakże separatystycznych zamierzeń wnioskodawców ${ }^{37}$. Przewidują konsekwencje, jakie ma przynieść uznanie języka śląskiego za regionalny. Podejmuje się próby kodyfikowania ortografii „śląskiej”; ma ona być nauczana w szkole ${ }^{38}$. Nie wiemy, która z gwar śląskich miałaby stać się podwaliną języka śląskiego (standardowego), a które jego wariantami. Ma zostać przygotowana kadra pedagogiczna i zaplecze dydaktyczne. Mają się pojawić napisy dwujęzyczne (ogólnopolski i śląski), a na Opolszczyźnie trójjęzyczne (oprócz polskich i niemieckich także śląskie) oraz modyfikacja zapisu nazwisk. A to już spowodowałoby określone skutki prawno-administracyjne...

Zwolennicy śląskiego języka regionalnego deklarują, że ich zamiarem jest ocalenie od zapomnienia odmiany języka, którą posługuje się starsze i średnie pokolenie. Nie zauważają przy tym, że pod wpływem czynników kulturowo-cywilizacyjnych dialekt także ulega zmianom. Względy emocjonalne przesłaniają separatystom racjonalną motywację, co więcej - prowadzą do ignorowania argumentów naukowych. Zauważmy, że rdzenni Ślązacy, uzmysławiający sobie wewnętrzne zróżnicowanie gwar śląskich - np. uczestnicy corocznych konkursów na „Ślązaka Roku”, będący nosicielami gwary w jej „czystej” postaci, nie upominają się o nadanie jej statusu języka, wręcz przeciwnie - pokazują, że „ich” mowa różni się właściwościami fonetycznymi czy gramatycznymi od mowy mieszkańców sąsiednich miejscowości (np. gwara cieszyńska od gwary Śląska przemysłowego i gwar Opolszczyzny).

Zabiegając o ,język regionalny”, wnioskodawcy akcentują czynnik demograficzno-społeczny. Nie przeprowadzono jednak dotychczas szeroko zakrojonych badań dialektologicznych z uwzględnieniem zasięgu i zakresu społecznej używalności kodu gwarowego ani badań nad kompetencją dialektalną mieszkańców Śląska z uwzględnieniem reprezentatywnych grup wiekowych - pokolenia młodego, średniego i starszego oraz grup społeczno-zawodowych. Wyniki tego typu badań byłyby istotne, ponieważ

37 Takie niebezpieczeństwo zauważają publicyści, np.: M. Narbutt, R. Mazurek, P. Semka („Rzeczpospolita”), M. Pańczyk-Pozdziej („Gość Niedzielny”) oraz naukowcy: ks. prof. C. Bartnik („Nasz Dziennik”), prof. F. Marek („Uważam Rze”), prof. M.M. Drozdowski („NGO”), potomkowie powstańców śl.: dr J. Musioł, C. Rymer („Dziennik Zachodni”), a także liczni czytelnicy gazet.

38 Ukazały się dwa elementarze, tzw. ślabikorze, opracowane przez nieprofesjonalistów (Górnoślonski ślabikorz, 2010; Ślabikorz ABC autorstwa B. Grynicz, A. Rocznioka 2010) i finansowane przez Sejmik Samorządowy województwa śląskiego. Zawierają one sporo różnych błędów oraz niedociągnięć: merytorycznych, ortograficznych i dydaktycznych. Występują w nich anachronizmy leksykalne, teksty są nieprzystosowane do współczesnych uwarunkowań kulturowych; uczenie gwarowego zapisu 9-letnich uczniów, którzy nie opanowali jeszcze zasad polskiej pisowni, będzie prowadzić do rozchwiania normy ortograficznej. „Ślabikorze” są wprowadzane do szkół śląskich fakultatywnie. W prasie śląskiej pojawiły się na ich temat pochlebne wypowiedzi bez wyczerpującego uzasadnienia. W jednym z nich (Grynicz, Roczniok, 2010) obserwujemy nieautentyczny przekaz gwarowy, nasycony nadmiernie germanizmami, a także wyrażeniami kolokwialnymi i wulgaryzmami. 
do niedawna za językiem regionalnym (śląskim) opowiadali się tylko rodowici Ślązacy, a teraz - coraz częściej - czynią to osoby, które upatrują w tym korzyści polityczne lub karierę.

\section{Uwagi o sytuacji polityczno-społeczno-edukacyjnej w województwie śląskim}

Skoro inicjatywę posła Marka Plury poparli liczni posłowie różnych ugrupowań, powinni oni poznać współczesną sytuację polityczno-społeczno-oświatową w województwie śląskim, w którym Jerzy Gorzelik, przywódca RAŚ, od 2011 r. odpowiada jako wicemarszałek Samorządowego Sejmiku Śląskiego za kulturę, wychowanie i edukację ${ }^{39}$ :

- wydano tu liczne materiały dydaktyczne, w tym ślabikorze (elementarze) o dyskusyjnej wartości merytorycznej,

- doszło do zalewu popularnej literatury śląskiej (o dość miernym poziomie),

- obserwujemy eskalację żądań autonomistów co do edukacji regionalnej z wykorzystaniem materiałów wydawanych przez nieprofesjonalistów, $\mathrm{z}$ tendencyjnie przedstawianymi faktami,

- pojawiają się na urzędach samorządowych flagi śląskie, a zdejmowane są chorągwie narodowe (biało-czerwone),

- zaczęto wieszać na urzędach miejskich tabliczki z napisami „Tu godomy po śląsku”,

- zniknęły (po remoncie) godła państwowe w salach urzędu miejskiego w Chorzowie.

Fakty te budzą niepokoje społeczne i świadczą o właściwych planach separatystów.

\section{Konieczność podniesienia prestiżu gwar i regionalizmów w Polsce}

W Uzasadnieniu mówi się również o podniesieniu prestiżu swojego dialektu (por. s. 9). Dążność taka jest zrozumiała i godna szacunku, ale nie można tego czynić w sposób nakazowy. Ustawa o języku polskim z 7 października 1999 r. w Art. 3, pkt. 1.4) mówi wyraźnie o „upowszechnianiu szacunku dla regionalizmów i gwar, a także przeciwdziałaniu ich zanikowi”. Wydaje się, że wystarczy administracyjnie wzmocnić te zapisy i podjąć rzeczywiste działania w celu ochrony i popularyzacji wartości regionalnych i podniesienia w Polsce pozycji gwar.

39 Przypomnijmy, że Ruch Autonomii Śląska zdobył w ubiegłych wyborach samorządowych poparcie 8,49\% wyborców i mimo tego, że nie stanowi reprezentatywnej siły w regionie, teraz jego przewodniczący decyduje w województwie śląskim o kluczowych dla teraźniejszości i przyszłości regionu sprawach, ma wpływ na obsadę stanowisk, na decyzje wydawnicze, w ten sposób może wpływać na kształtowanie tożsamości i świadomości narodowej, zwłaszcza młodego pokolenia. 
Fenomenem było trwanie przy śląskiej mowie i obyczaju przez kilkaset lat przynależności Śląska do Czech od poł. XIV w., do państwa Habsburgów od 1526 r. i po jego podziale po wojnach śląskich z poł. XVIII w. w części niemieckiej i tzw. cesarskiej (austriackiej) do końca I wojny światowej. Śląszczyznę słyszy się dziśs ${ }^{0}$ i nad Ostrawicą w Czechach na Zaolziu, i w okolicach Głubczyc, Opola, Kluczborka. Należy podkreślać i eksponować to, że mowa śląska pozostała w strukturze polska (z cechami dźwiękowymi i morfologicznymi staropolszczyzny), że przetrwał śląski obyczaj i o tym uczyć w szkole, przekazywać rzetelną wiedzę o regionie i gwarze. Gdyby świadomość bycia kimś innym (nie-Niemcem) nie była tak silna na Śląsku, gdyby w kościołach nie modlono się (rzykano) po polsku - nie doszłoby do powstań ${ }^{41}$. Nie byłoby plebiscytu, który moralnie był wygrany ${ }^{42}$. A teraz niektórzy działacze próbują deprecjonować i powstania śląskie, i inne przejawy polskości na Śląsku.

Jestem zdania, że wsparcie państwa powinno wzmacniać wszystkie polskie gwary, łącznie z polszczyzną Zabużan, których dotknęła ekspatriacja, oraz tych Polaków, którzy na skutek zmian granic żyją poza ojczyzną, a chcą zachować polskość (jak zaolziańscy Ślązacy).

\section{Zakończenie}

W zakończeniu należy podkreślić, że treść Uzasadnienia, zawierająca liczne błędy, niejasne sformułowania, nadinterpretacje oraz fragmenty dezinformujące i nieprawdziwe tezy, nie może być traktowana jak tekst wyjaśniający zasadność proponowanych zmian ustawodawczych. Przedstawiona nowelizacja nie jest zgodna z Europejską kartą języków regionalnych lub mniejszościowych (por. art.1 a), ponieważ gwara śląska jest ewidentnym polskim dialektem oraz dlatego, że nie współgra $\mathrm{z}$ ideą zawartą w Preambule Europejskiej karty... w której mówi się wyraźnie o tym, że „ochrona języków regionalnych lub mniejszościowych i poparcie dla nich nie powinny przebiegać ze szkodą dla języków oficjalnych i potrzeby ich poznawania". Dodajmy, że autorzy Europejskiej karty..., popierając różnorodność kulturową, stoją równocześnie na straży „suwerenności narodowej oraz integralności terytorialnej” państwa, w którym występują języki regionalne i mniejszościowe.

40 Por. badania dialektologiczne prowadzone na Zaolziu, działalność PZKO (Polskiego Związku Kulturalno-Oświatowego) oraz Centrum Pedagogicznego dla Polskiego Szkolnictwa Narodowościowego w Cieszynie.

41 Dodajmy, że powstania miały charakter plebejski, że swym zasięgiem ogarnęły nie tylko teren przemysłowy, ale znaczną część Opolszczyzny i wraz z powstaniem wielkopolskim były jedynymi zwycięskimi zrywami patriotycznymi w Polsce.

42 Por. wyniki plebiscytu i teren, który był objęty głosowaniem. 


\section{Streszczenie}

Opinia o projekcie nowelizacji ustawy ma charakter negatywny ze względu na brak zgodności z przepisami polskimi (Ustawa o języku polskim z 07.10.1999) oraz unijnymi (Europejska karta języków regionalnych i mniejszościowych). Wnioskodawcy chcą doprowadzić do uznania regionalnego języka śląskiego. Tymczasem klasyfikacja obowiązująca do tej pory w stosunku do używanych (żywych) języków świata wyróżnia opozycyjnie język ogólny (ogólnonarodowy) i jego odmiany regionalne/ terytorialne - gwary. Nie ma żadnych racjonalnych powodów, by zmieniać dotychczasowe ustalenia i doprowadzić do preferowania jednego z polskich dialektów, ustanawiając go językiem regionalnym. Można jednak, ze względu na osłabioną (z powodów historycznych) pozycję gwar i polszczyzny regionalnej dążyć do podniesienia prestiżu dialektów w Polsce.

\section{Opinion on draft amendments to the law on national and ethnic minorities and regional language, and on some other laws \\ Summary}

The opinion on draft amendments is negative due to lack of compliance with the Polish and EU regulations (Act on the Polish Language from 1999.10.07 and the European Charter for Regional or Minority Languages). Applicants want Silesian to be recognized as a national language. However, the current classification of used (living) languages of the world contrasts the general (nationwide) language with its regional/territorial varieties, i.e. subdialects. There are no rational arguments for modification of the existing arrangements, and favouring one of Polish dialects by establishing it as a regional language. Since, however, the positions of subdialects and regional Polish have been weakened for historical reasons, it will be justified to seek to raise their prestige. 